\begin{tabular}{|c|c|c|c|c|}
\hline $\begin{array}{c}\text { Prosiding Penelitian \& } \\
\begin{array}{c}\text { Pengabdian Kepada } \\
\text { Masyarakat }\end{array}\end{array}$ & $\begin{array}{c}\text { e ISSN : 2581-1126 } \\
\text { p ISSN : 2442-448X }\end{array}$ & Vol 5, No: 2 & Hal: $137-145$ & Juli 2018 \\
\hline
\end{tabular}

\title{
TINGKAT PENDAPATAN PETUGAS K3L UNIVERSITAS PADJADJARAN
}

\author{
Khofiyya Fathimah Az Zahra Fahdita ${ }^{1}$, Ishartono ${ }^{2}$ \\ Fakultas Ilmu Sosial dan Ilmu Politik, Universitas Padjadjaran \\ e-mail: khofiyya17001@mail.unpad.ac.id, ishartono_kesos@yahoo.com
}

\begin{abstract}
ABSTRAK
Jatinangor dikenal sebagai wilayah pendidikan karena pembangunan kampus beberapa institusi perguruan tinggi, yaitu UNPAD di Desa Hegarmanah dan Desa Cikeruh, IPDN (sebelumnya bernama STPDN) di Desa Cibeusi, IKOPIN di Desa Cibeusi, dan ITB di Desa Sayang. Karena adanya perubahan tatanan struktur sosial, maka mata pencaharian masyarakat Kabupaten Sumedang mulai berubah yang awalnya sebagai petani sekarang bekerja sebagai pekerja buruh, bekerja di tempat-tempat institusi pendidikan dan lain-lain. Salah satunya bekerja sebagai petugas K3L Universitas Padjadjaran. Petugas K3L Universitas Padjadjaran ini berasal dari warga masyarakat Kabupaten Sumedang yang ingin mencari atau menambah penghasilan keluarga untuk memenuhi kebutuhan sehari-hari dan biaya pendidikan anak-anaknya. Hasil dari penelitian ini menunjukkan bahwa dominan petugas K3L ini berasal dari kaum wanita yang sudah berstatus kawin. Penelitian ini juga menunjukkan bahwa yang membayar upah petugas K3Ladalah Universitas Padjadjaran bukan kontraktor atau perusahaan jasa. Penelitian ini bermaksud untuk mengetahui tingkat pendapatan petugas K3L Universitas Padjadjaran. Berdasarkan hasil penelitian pendapatan yang diterima oleh petugas K3L Universitas Padjadjaran adalah sebesar Rp. 750.000/bulan. Jika dibandingkan dengan UMKabupaten Sumedang tahun 2017, yaitu sebesar Rp. 2.678.028,99/bulan maka dapat disimpulkan bahwa tingkat pendapatan petugas K3L Universitas Padjadjaran termasuk rendah. Adapun untuk mendapatkan informasi mengenai data-data yang mendukung terhadap penelitian yang kami lakukan ialah dengan menggunakan metode wawancara terstruktur dengan menggunakan kuisioner dan pendekatan kuantitatif.
\end{abstract}

Kata kunci : Ketenagakerjaan, Petugas K3L Universitas Padjadjaran, Pendapatan

\section{ABSTRACT}

Jatinangor is known as an educational area due to the construction of several university campuses, namely UNPAD in Hegarmanah and Cikeruh villages, IPDN (formerly STPDN) in Cibeusi Village, IKOPIN in Cibeusi Village, and ITB in Sayang Village. Due to the change of the structure of the social structure, the livelihood of the people of Sumedang Regency began to change which initially as farmers now work as laborers, work in places of educational institutions and others. One of them works as an officer of K3L Universitas Padjadjaran. The K3L officer of Padjadjaran University is from Sumedang people who want to find or supplement the family's income to meet their daily needs and education cost of their children. The results of this study indicate that the dominant $\mathrm{K} 3 \mathrm{~L}$ officer is derived from women who have married status. This study also shows that those who pay K3L officer wage is Padjadjaran University is not contractor or service company. This research intends to know the income level of K3L officer of Padjadjaran University. Based on the results of research income received by officers K3L Padjadjaran University is Rp. 750.000 / month. Compared with the Sumedang MSE in 2017, which is Rp. 2.678.028,99/ month it can be concluded that the income level of K3L officers of Universitas Padjadjaran is low. As for getting information about the data that support the research we do is to use structured interview method by using questionnaire and quantitative approach.

Keywords: Employment, K3L officer of Padjadjaran University, income

\footnotetext{
${ }^{1}$ Mahasiswa Kesejahteraan Sosial Fakultas IImu Sosial dan IImu Politik Universitas Padjadjaran

${ }^{2}$ Dosen Kesejahteraan Sosial Fakultas IImu Sosial dan IImu Politik Universitas Padjadjaran
} 


\begin{tabular}{|c|c|c|c|c|}
\hline $\begin{array}{c}\text { Prosiding Penelitian \& } \\
\begin{array}{c}\text { Pengabdian Kepada } \\
\text { Masyarakat }\end{array}\end{array}$ & $\begin{array}{c}\text { e ISSN : 2581-1126 } \\
\text { p ISSN : 2442-448X }\end{array}$ & Vol 5, No: 2 & Hal: $137-145$ & Juli 2018 \\
\hline
\end{tabular}

\section{PENDAHULUAN}

Ekonomi merupakan aktivitas kegiatan manusia di muka bumi ini, sehingga kemudian timbul motif ekonomi, yaitu keinginan seseorang untuk dapat memenuhi kebutuhan hidupnya. Dalam kehidupan sehari-hari orang cenderung menyamakan kebutuhan (needs) dengan keinginan (wants). Seringkali orang menyebutkan sesuatu sebagai kebutuhan yang harus dipenuhi segera, padahal sesuatu tersebut berupa keinginan yang bisa saja ditunda. Menurut Rochmawan (2008:4) Kebutuhan manusia banyak dan beraneka ragam, bahkan tidak hanya beraneka ragam tetapi bertambah terus tidak ada habisnya sejalan dengan perkembangan peradaban dan kemajuan ilmu pengetahuan dan teknologi. Satu kebutuhan telah terpenuhi, tentu akan datang lagi kebutuhan yang lainnya. Kebutuhan adalah keinginan manusia terhadap barang dan jasa yang harus dipenuhi, dan jika tidak dipenuhi akan berpengaruh terhadap keberlangsungan hidupnya atau bisa menimbulkan dampak negatif.

Jatinangor dikenal sebagai wilayah pendidikan karena pembangunan beberapa institusi perguruan tinggi, yaitu UNPAD di Desa Hegarmanah dan Desa Cikeruh, IPDN (sebelumnya bernama STPDN) di Desa Cibeusi, IKOPIN di Desa Cibeusi, dan ITB di Desa Sayang. Sehingga secara fisik terjadi berbagai perubahan akibat pembangunan infrastruktur di Jatinangor ini. Dengan beralihnya lahan pertanian menjadi apartemen, kos-kosan, mall, dan institusi pendidikan, maka terjadi pula perubahan tatanan struktur sosial. Masyarakat tersebut dituntut untuk memiliki keahlian untuk bisa memperoleh penghasilan dan untuk bertahan hidup. Adanya apartemen, kos-kosan, mall, dan istitusi di wilayah Kabupaten Sumedang juga merupakan suatu peluang untuk maju bagi masyarakat.

Universitas Padjadjaran merupakan salah satu institusi perguruan tinggi negeri yang membuka peluang bagi masyarakat Kabupaten Sumedang untuk bekerja. Salah satunya adalah bekerja sebagai petugas K3L (Kebersihan Keindahan Kenyamanan Lingkungan) Universitas Padjadjaran. Petugas K3L ini bertanggung jawab atas kebersihan yang berada di lingkungan Universitas Padjadjaran seperti membersihkan jalan atau pekarangan gedung, keindahan di lingkungan Universitas Padjadjaran, kenyamanan di lingkungan Universitas Padjadjaran sehingga masyarakat yang berada di lingkungan merasa nyaman karena lingkungan yang bersih dan tertata rapih. Karena dominan Petugas K3L ini adalah wanita, maka mereka bekerja untuk membantu perekonomian keluarga atau sebagai pendapatan pokok. Pendapatan ini mempengaruhi tingkat perekonomian K3L Universitas Padjadjaran.

Hal ini senada dengan pernyataan dari Sujarwati (2013) bahwa partisipasi wanita dalam dunia kerja, telah memberikan kontribusi yang besar terhadap kesejahteraan keluarga, khususnya bidang ekonomi (Sujarwati, 2013). Untuk itu dengan meningkatnya partisipasi wanita bekerja untuk membantu perekonomian. Hal sangat mempengaruhi peran ibu dalam kehidupan perekonomian selain itu wanita juga mempunyai peran ganda yaitu sebagai peran ibu dan istri dalam rumah tangga dan peran wanita dalam bekerja yang tidak menggangu kehidupan keluarga. Dengan adanya tambahan pendapatan dalam keluarga diharapkan kesejahteraan keluarga meningkat karena semua kebutuhan terpenuhi.

Menurut Abdullah, keterlibatan wanita dalam industri rumah tangga dipengaruhi oleh beberapa faktor. Pertama, tekanan ekonomi. Kedua, lingkungan keluarga yang sangat mendukung dalam bekerja, misalnya: mereka terbiasa membantu orang-orang di sekitarnya yang mengusahakan industri rumah tangga. Ketiga, tidak ada peluang kerja lain yang sesuai dengan keterampilannya. Kondisi kemiskinanlah yang mendorong perempuan untuk ikut mengambil alih tanggung jawab ekonomi keluarga. Dengan berbagai cara perempuan ikut berperan aktif menaikkan pendapatan. Perempuan bekerja saat ini bukan lah masalah baru, adapun beberapa alasan yang dikemukakan bagi wanita yang bekerja diluar rumah antara lain:

1. Menambah pendapatan keluarga (family income) terutama jika pendapatan suami relative kecil,

2. Memanfaatkan berbagai keunggulan (pendidikan, keterampilan) yang dimilikinya yang diharapkan oleh keluarganya, 


\begin{tabular}{|c|c|c|c|c|}
\hline $\begin{array}{c}\text { Prosiding Penelitian \& } \\
\begin{array}{c}\text { Pengabdian Kepada } \\
\text { Masyarakat }\end{array}\end{array}$ & $\begin{array}{c}\text { e ISSN : 2581-1126 } \\
\text { p ISSN : 2442-448X }\end{array}$ & Vol 5, No: 2 & Hal: $137-145$ & Juli 2018 \\
\hline
\end{tabular}

3. Menunjukkan eksistensi sebagai manusia (aktualisasi diri) bahwa ia mampu berprestasi dalam kehidupan masyarakat,

4. Untuk memperoleh status atau kekuasaan lebih besar didalam kehidupan keluarga (Hendi Suhendi, 2001: 173)

\section{Pengertian Ketenagakerjaan}

Dalam Undang-Undang Republik Indonesia Nomor 13 Tahun 2003 Tentang Ketenagakerjaan, dikatakan bahwa ketenagakerjaan adalah segala hal yang berhubungan dengan tenaga kerja pada waktu sebelum, selama, dan sesudah masa kerja. Dari pengertian tersebut dapat dipahami bahwa ketenagakerjaan merupakan segala sesuatu yang berkaitan dengan pekerja/buruh, baik menyangkut hal-hal yang ada sebelum masa kerja (preemployment), selama masa bekerja (duringemployment), maupun sesudah masa kerja. Ketenagakerjaan tidak terlepas dari masalah kesempatan kerja, tenaga kerja dan angkatan kerja. Penduduk suatu negara dapat dibagi dalam dua kelompok, yakni kelompok penduduk usia kerja (tenaga kerja) dan kelompok penduduk bukan usia kerja. Penduduk usia kerja (tenaga kerja) adalah penduduk yang berumur 15 tahun ke atas untuk negara-negara berkembang seperti Indonesia. Sedangkan penduduk bukan usia kerja adalah penduduk yang berumur 0 hingga 14 tahun, untuk negara-negara berkembang seperti Indonesia (Erlangga, 2014).

Tenaga kerja dapat pula dibagi dalam dua kelompok, yakni kelompok angkatan kerja dan kelompok bukan angkatan kerja. Angkatan kerja adalah penduduk dalam usia kerja (15 tahun ke atas), baik yang bekerja maupun yang tidak bekerja. Kelompok ini biasa disebut sebagai kelompok usia produktif. Namun, tidak semua angkatan kerja dalam suatu negara mendapat kesempatan bekerja. Mereka inilah yang disebut penganggur. Penganggur adalah penduduk tidak bekerja, sedang mencari pekerjaan, atau sedang mempersiapkan suatu usaha baru. Sedangkan kelompok bukan angkatan kerja adalah mereka yang sekolah, mengurus rumah tangga, dan penerima pendapatan. Proporsi pendukung yang tergolong angkatan kerja adalah masyarakat yang aktif dalam kegiatan ekonomi.
Kesempatan kerja adalah tersedianya lapangan kerja bagi angkatan kerja yang membutuhkan pekerja. Kesempatan kerja di Indonesia dijamin dalam Pasal 27 ayat 2 UUD 1945 yang berbunyi: "Tiap-tiap warga negara berhak atas pekerjaan dan penghidupan yang layak."

Penduduk Kabupaten Sumedang berdasarkan proyeksi penduduk tahun 2016 sebanyak 1.142.097 jiwa yang terdiri atas 569.024 jiwa penduduk laki-laki dan 573.073 jiwa penduduk perempuan. Dibandingkan dengan proyeksi jumlah penduduk tahun 2015, penduduk Kabupaten Sumedang mengalami pertumbuhan sebesar 0,42 persen. Sementara itu besarnya angka rasio jenis kelamin penduduk laki-laki terhadap penduduk perempuan tahun 2016 sebesar 99,29. Hal ini berarti dapat dikatakan bahwa dalam 100 penduduk perempuan terdapat 99 penduduk lakilaki (BPS, 2017)

\section{Petugas K3L Universitas Padjadjaran}

Petugas K3L merupakan salah satu pekerjaan yang disediakan oleh Universitas Padjadjaran sebagai salah satu bentuk penyediaan kesempatan bagi masyarakat sekitar Jatinangor dan wilayah lain yang berada di Kabupaten Sumedang untuk memperoleh pekerjaan dan penambahan pendapatan keluarga guna membantu dalam mewujudkan pememuhan kebutuhannya. K3L ini merupakan kepanjangan dari Kebersihan Keindahan dan Kenyamanan Lingkungan, sehingga melihat dari pengertiannya pun petugas K3L Universitas Padjadjaran bertugas menjaga kebersihan keindahan dan kenyamanan lingkungan Universitas Padjadjaran, namun petugas K3L Universitas Padjadjaran ini hanya bertugas menjaga kawasan diluar gedung kampus Universitas.

\section{Pengertian Pendapatan}

Dalam Kamus Besar Bnmahasa Indonesia pendapatan adalah hasil kerja (usaha atau sebagainya) (Departemen Pendidikan dan Kebudayaan, 1998:185). Sedangkan pendapatan dalam kamus manajemen adalah uang yang diterima oleh perorangan, perusahan dan organisasi lain dalam bentuk upah, gaji, sewa, bunga, komisi, ongkos dan laba (BN.Marbun, 2003: 230). Pendapatan seseorang juga dapat 


\begin{tabular}{|c|c|c|c|c|}
\hline $\begin{array}{c}\text { Prosiding Penelitian \& } \\
\begin{array}{c}\text { Pengabdian Kepada } \\
\text { Masyarakat }\end{array}\end{array}$ & $\begin{array}{c}\text { e ISSN : 2581-1126 } \\
\text { p ISSN : 2442-448X }\end{array}$ & Vol 5, No: 2 & Hal: $137-145$ & Juli 2018 \\
\hline
\end{tabular}

didefiniskan sebagai banyaknya penerimaan yang dinilai dengan satuan mata uang yang dapat dihasilkan seseorang atau suatu bangsa dalam periode waktu tertentu. Reksoprayitno mendefinisikan: "Pendapatan (revenue) dapat diartikan sebagai total penerimaan yang diperoleh pada periode waktu tertentu". Dengan demikian dapat disimpulkan bahwa pendapatan adalah sebagai jumlah penghasilan yang diterima oleh anggota masyarakat untuk jangka waktu tertentu sebagai balas jasa atau faktor-faktor produksi yang telah disumbangkan (Reksoprayitno, 2004: 79).

Pendapatan masyarakat adalah penerimaan dari gaji atau balas jasa dari hasil usaha atau sumber lain yang diperoleh individu atau kelompok rumah tangga yang dalam satu bulan digunakan untuk kebutuhan sehari-hari. Sedangkan pendapatan dari usaha sampingan adalah pendapatan tambahan yang merupakan penerimaan lain dari luar aktivitas pokok atau pekerjaan pokok. Pendapatan sampingan yang diperoleh secara langsung dapat digunakan untuk menunjang atau menambah pendapatan pokok.

Soekartawi menjelaskan pendapatan akan mempengaruhi banyaknya barang yang dikonsumsikan, bahwa sering kali dijumpai dengan bertambahnya pendapatan, maka barang yang dikonsumsi bukan saja bertambah, tapi juga kualitas barang tersebut ikut menjadi perhatian. Misalnya sebelum adanya penambahan pendapatan beras yang dikonsumsikan adalah kualitas yang kurang baik, akan tetapi setelah adanya penambahan pendapatan maka konsumsi beras menjadi kualitas yang lebih baik (Soekartawi, 2002: 132).

Seperti halnya yang dikemukakan Toweulu bahwa "Untuk memperbesar pendapataan, seseorang anggota keluarga dapat mencari pendapatan dari sumber lain atau membantu pekerjaan kepala keluarga sehingga pendapatannya bertambah (Sudarman Toweulu, 2001: 3).

\section{Faktor-Faktor Yang Mempengaruhi Pendapatan}

Faktor-faktor yang mempengaruhi pendapatan Menurut Bintari, Suprihatin (1984):

a) Kesempatan kerja yang tersedia
Dengan semakin tinggi atau semakin besar kesempatan kerja yang tersedia berarti banyak penghasilan yang bisa diperoleh dari hasil kerja tersebut.

b) Kecakapan dan keahlian kerja

Dengan bekal kecakapan dan keahlian yang tinggi akan dapat meningkatkan efisiensi dan efektifitas yang pada akhirnya berpengaruh pula terhadap penghasilan.

c) Kekayaan yang dimiliki

Jumlah kekayaan yang dimiliki seseorang juga mempengaruhi jumlah penghasilan yang diperoleh. Semakin banyak kekayaan yang dimiliki berarti semakin besar peluang untuk mempengaruhi penghasilan.

d) Keuletan kerja

Pengertian keuletan dapat disamakan dengan ketekunan dan keberanian untuk menghadapi segala macam tantangan. Bila suatu saat mengalami kegagalan, maka kegagalan tersebut dijadikan sebagai bekal untuk meniti ke arah kesuksesan dan keberhasilan.

e) Banyak sedikitnya modal yang digunakan Suatu usaha yang besar akan dapat memberikan peluang yang besar pula terhadap penghasilan yang akan

\section{METODE}

Penelitian ini dimaksudkan untuk menggambarkan mengenai tingkat pendapatan K3L Universitas Padjadjaran. Adapun untuk mendapatkan informasi mengenai data-data yang mendukung terhadap penelitian yang kami lakukan ialah dengan menggunakan metode wawancara terstruktur dengan menggunakan kuisioner dan pendekatan kuantitatif. Populasi yang penulis tuju adalah pekerja K3L Universitas Padjadjaran dengan menggunakan sampel sebanyak 12 orang yang diambil secara accidental sampling. Pengumpulan data dalam kegiatan ini menggunakan data primer dan data sekunder dengan cara melakukan observasi langsung turun ke lapangan dan melakukan wawancara secara langsung

\section{HASIL DAN PEMBAHASAN}

Jatinangor dikenal sebagai wilayah pendidikan karena pembangunan beberapa institusi perguruan 


\begin{tabular}{|c|c|c|c|c|}
\hline $\begin{array}{c}\text { Prosiding Penelitian \& } \\
\begin{array}{c}\text { Pengabdian Kepada } \\
\text { Masyarakat }\end{array}\end{array}$ & $\begin{array}{c}\text { e ISSN : 2581-1126 } \\
\text { p ISSN : 2442-448X }\end{array}$ & Vol 5, No: 2 & Hal: $137-145$ & Juli 2018 \\
\hline
\end{tabular}

tinggi, yaitu UNPAD di Desa Hegarmanah dan Desa Cikeruh, IPDN (sebelumnya bernama STPDN) di Desa Cibeusi, IKOPIN di Desa Cibeusi, dan ITB di Desa Sayang. Sehingga secara fisik terjadi berbagai perubahan akibat pembangunan infrastruktur di Jatinangor ini. Dengan beralihnya lahan pertanian menjadi apartemen, kos-kosan, mall, dan institusi pendidikan, maka terjadi pula perubahan tatanan struktur sosial. Masyarakat tersebut dituntut untuk memiliki keahlian untuk bisa memperoleh penghasilan dan untuk bertahan hidup. Universitas Padjadjaran merupakan salah satu institusi perguruan tinggi negeri yang membuka peluang bagi masyarakat Kabupaten Sumedang untuk bekerja. Salah satunya adalah bekerja sebagai petugas K3L (Kebersihan Keindahan Kenyamanan Lingkungan) Universitas Padjadjaran.

Dulu petugas K3L Universitas Padjadjaran ini menggunakan jasa Outsourching. Outsourcing merupakan pendelegasian operasi dan manajemen harian dari suatu proses bisnis kepada pihak luar (perusahaan penyedia jasa outsourcing). Hubungan kerja yang dilakukan antara lain perjanjian kerja kontrak atau perjanjian kerja waktu tertentu (PKWT), dan outsourcing. PKWT atau pekerja kontrak direkrut langsung oleh perusahaan pengguna tenaga kerja, sedangkan outsourcing direkrut melalui perusahaan penyedia jasa tenaga kerja. Berdasarkan Undang-Undang No. 13/2003 pada Pasal 64, pengertian hubungan kerja sistem outsourcing hanya dapat dilakukan melalui dua bentuk perjanjian kerja yang dibuat secara tertulis, yaitu (1) pemborongan pekerjaan, atau (2) penyedia jasa pekerja/buruh. Dengan demikian, praktik hubungan kerja sistem outsourcing menimbulkan pihak ketiga dalam hubungan kerja antara pekerja dengan perusahaan, yakni perusahaan pemborongan atau perusahaan penyedia jasa tenaga kerja/buruh.

Alasan utama outsourcing adalah (Hadi Setia Tunggal, 2013:19) :

1. Meningkatkan konsentrasi bisnis. Kegiatan operasional telah dilimpahkan kepada pihak lain.

2. Membagi resiko operasional. Outsourcing membuat risiko operasional perusahaan bisa terbagi kepada pihak lain.
3. Sumber daya perusahaan yang ada bisa dimanfaatkan untuk kebutuhan yang lainnya.

4. Effisiensi biaya. Pemanfaatan dana yang sebelumnya digunakan untuk investasi bisa difungsikan sebagai biaya operasional.

5. Memperkerjakan sumber daya manusia (SDM) yang berkompeten karena tenaga kerja yang disediakan oleh perusahaan Outsourcing adalah tenaga yang sudah terlatih dan kompeten di bidangnya.

6. Mekanisme kontrol menjadi lebih baik

Tetapi berbeda dengan sekarang, Universitas Padjadran sudah tidak menggunakan jasa outsorching lagi. Sekarang Universitas Padjadjaran yang menyaring masyarakat Kabupaten Sumedang untuk bekerja sebagai Petugas K3L Universitas Padjadjaran. Universitas Padjadjaran juga yang membayar gaji kepada para petugas K3L Universitas Padjadjaran.

Tabel 1. Instansi yang Membayar Gaji Petugas K3L

\begin{tabular}{|l|c|c|}
\hline Golongan & Frekuensi & $\%$ \\
\hline Unpad & 12 & $100 \%$ \\
\hline Kontraktor & 0 & $0 \%$ \\
\hline JUMLAH & 12 & $100 \%$ \\
\hline
\end{tabular}

Sumber : Hasil Penelitian 2018

Jika dilihat dari jenis kelaminnya, berdasarkan hasil penelitian yang dilakukan, sebanyak $58 \%$ petugas K3L Universitas Padjadjaran dominan berjenis kelamin perempuan dan sebanyak $42 \%$ petugas K3L Universitas Padjadjaran berjenis kelamin lakilaki. Maka dari hasil penelitian tersebut terlihat bahwa di era globalisasi ini adanya kesetaraan gender antara perempuan dan laki-laki. Bukan hanya laki-laki saja yang bekerja untuk memenuhi kebutuhan sehari-hari melainkan sekarang perempuan juga yang tadinya hanya sebagai ibu rumah tangga sekarang perempuan membantu perekonomian keluarga. Perempuan juga sangat berpengaruh dalam dunia kerja di era globalisasi ini. Di dalam dunia kerja sekarang sudah tidak melihat dari sudut jenis kelamin baik itu laki-laki atau perempuan selama orang itu memiliki soft skill, tanggung jawab dan jujur pekerjaan itu bisa dikerjakan oleh siapapun. 


\begin{tabular}{|c|c|c|c|c|}
\hline $\begin{array}{c}\text { Prosiding Penelitian \& } \\
\begin{array}{c}\text { Pengabdian Kepada } \\
\text { Masyarakat }\end{array}\end{array}$ & $\begin{array}{c}\text { e ISSN : 2581-1126 } \\
\text { p ISSN : 2442-448X }\end{array}$ & Vol 5, No: 2 & Hal: $137-145$ & Juli 2018 \\
\hline
\end{tabular}

Petugas K3L Universitas Padjadjaran ini berumur antara 25 tahun hingga 64 tahun. Dari hasil penelitian yang dilakukan pada rentang umur 45 tahun sampai 49 tahun adalah umur paling dominan sebanyak $33 \%$ yang bekerja sebagai petugas K3L Universitas Padjadjaran ini. Karena pada usia terebut merupakan penduduk usia kerja (tenaga kerja) adalah penduduk yang berumur 15 tahun ke atas untuk negara-negara berkembang seperti Indonesia. Sedangkan penduduk bukan usia kerja adalah penduduk yang berumur 0 hingga 14 tahun, untuk negara-negara berkembang seperti Indonesia.

Dari hasil penelitian yang dilakukan, petugas $\mathrm{K} 3 \mathrm{~L}$ Universitas Padjadjaran pada umumnya sebanyak $50 \%$ berpendidikan terakhir Sekolah Dasar (SD). Jenis pekerjaan $\mathrm{K} 3 \mathrm{~L}$ ini termasuk ke dalam jenis klasifikasi pekerjaan tidak terdidik dan tidak terlatih.

Klasifikasi tenaga kerja (Dwiyanto, Agus, dkk, 2006: 45) :

1) Berdasarkan kualitasnya

a. Tenaga kerja terdidik

Tenaga kerja terdidik adalah tenaga kerja yang memiliki suatu keahlian atau kemahiran dalam bidang tertentu dengan cara sekolah atau pendidikan formal dan nonformal. Contohnya: pengacara, dokter, guru, dan lainlain.

b. Tenaga kerja terlatih

Tenaga kerja terlatih adalah tenaga kerja yang memiliki keahlian dalam bidang tertentu dengan melalui pengalaman kerja.

Tenaga kerja terampil ini dibutuhkan latihan secara berulang-ulang sehingga mampu menguasai pekerjaan tersebut. Contohnya: apoteker, ahli bedah, mekanik, dan lain-lain

c. Tenaga kerja tidak terdidik dan tidak terlatih

Tenaga kerja tidak terdidik dan tidak terlatih adalah tenaga kerja kasar yang hanya mengandalkan tenaga saja. Contoh: kuli, buruh angkut, pembantu rumah tangga, dan sebagainya.

Penelitian ini juga menunjukkan bahwa petugas K3L sebanyak $83 \%$ sudah berstatus kawin. Penduduk usia kerja (tenaga kerja) adalah penduduk yang berumur 15 tahun ke atas untuk negara-negara berkembang seperti Indonesia. Maka dari itu pada usia produktif tersebut mereka sudah berstatus kawin dan harus memiliki pekerjaan untuk memenuhi kebutuhan sehari-hari. Juga untuk membayar pendidikan anak-anaknya yang membutuhkan uang banyak untuk melanjutkan pendidikan ke jenjang yang lebih tinggi agar bisa memiliki pekerjaan yang layak untuk kehidupan yang lebih baik lagi.

Penelitian ini juga menunjukkan bahwa tempat tinggal petugas $\mathrm{K} 3 \mathrm{~L}$ ini pada umumnya tinggal di tempat tinggal yang jaraknya jauh dari wilayah Universitas Padjadjaran seperti di Tanjungsari. Hanya sekitar $8 \%$ petugas K3L yang bertempat tinggal di wilayah yang dekat dengan lingkungan Universitas Padjadjaran. Maka bisa ditarik kesimpulan bahwa adanya kesenjangan antara warga masyarakat yang berada di sekitar Universitas Padjadjaran dengan warga masyarakat yang letaknya agak jauh dari wilayah Universitas Padjadjaran. Warga masyarakat yang berada di sekitar daerah Universitas Padjadjaran biasanya mencari penghasilan dengan menjual jasa atau barang terhadap mahasiswa Universitas Padjadjaran yang bisa menghasilkan uang.

Kesenjangan sosial adalah suatu keadaan tidak seimbangan sosial yang ada di masyarakat yang menjadikan suatu perbedaan. Kesenjangan sosial juga merupakan distribusi yang tidak merata (ketidakadilan dan ketidaksetaraan) yang dialami oleh individu dan kelompok yang dianggap penting dalam suatu masyarakat dan penilaian tidak sama serta pengecualian berdasarkan posisi sosial dan gaya hidup. Juga hak dan kewajiban tidak didistribusikan secara merata atau ketidaksamaan akses untuk mendapatkan atau memanfaatkan sumber daya yang tersedia. Sumber daya bisa berupa kebutuhan primer, seperti pendidikan, kesehatan, perumahan, peluang berusaha dan kerja. Dapat pula berupa kebutuhan sekunder, seperti sarana pembangunan usaha, sarana 


\begin{tabular}{|c|c|c|c|c|}
\hline $\begin{array}{c}\text { Prosiding Penelitian \& } \\
\text { Pengabdian Kepada } \\
\text { Masyarakat }\end{array}$ & $\begin{array}{c}\text { e ISSN : 2581-1126 } \\
\text { p ISSN : 2442-448X }\end{array}$ & Vol 5, No: 2 & Hal: $137-145$ & Juli 2018 \\
\hline
\end{tabular}

perjuangan hak asasi, sarana saluran politik, pemenuhan pengembangan karier, dan lain-lain.

Tabel 2. Besarnya Gaji yang Diterima Petugas K3L Universitas Padjadjaran

\begin{tabular}{|l|c|c|}
\hline $\begin{array}{c}\text { Golongan } \\
\text { (Rp/Bulan) }\end{array}$ & Frekuensi & $\%$ \\
\hline $700-799$ & 12 & $100 \%$ \\
\hline $800-999$ & 0 & 0 \\
\hline $1.000-1.119$ & 0 & 0 \\
\hline $1.200-1.400$ & 0 & 0 \\
\hline JUMLAH & 12 & $100 \%$ \\
\hline
\end{tabular}

Sumber : Hasil Penelitian 2018

Dari tabel tersebut dapat disimpulkan bahwa besarnya gaji yang diterima oleh perugas $\mathrm{K} 3 \mathrm{~L}$ Universitas Padjadjaran adalah sebesar Rp.700.000 sampai Rp. 799.000. Pada saat melakukan wawancara, awalnya gaji yang mereka dapatkan hanya sebesar Rp. 650.000. Kemudian ada kenaikan gaji yang berlangsung dua kali menjadi Rp. 750.000 per bulan. Gaji yang mereka terima juga belum mencukupi kebutuhan pokok karena pengeluaran yang mereka keluarkan lebih banyak daripada pendapatan yang mereka terima. Tetapi mereka mengatakan bahwa dengan bekerja sebagai petugas K3L Universitas Padjadjaran cukup membantu untuk kehidupan sehari-sehari daripada sebelumnya bagi mereka yang hanya sebagai ibu rumah tangga yang tidak mendapatkan penghasilan.

Menurut Keputusan Gubernur Jawa Barat Nomor : 561/Kep.1065-Yanbangsos/2017 Upah Minimum Kabupaten Sumedang yang sudah di sahkan oleh Gubernur Jawa Barat per 1 Januari 2018 yaitu sebesar Rp. 2.678.028,99. Upah Minimum Kabupaten Sumedang tersebut cukup besar dibandingkan dengan Upah Minimum kabupatenkabupaten lain yang berada di wilayah Provinsi Jawa Barat. Jadi dapat disimpulkan bahwa tingkat pendapatan yang diterima oleh petugas K3L Universitas Padjadjaran Padjadjaran termasuk rendah, karena di bawah UMKabupaten Sumedang.

Tabel 3. Adanya Tidaknya Lembur

\begin{tabular}{|l|c|c|}
\hline Golongan & Frekuensi & $\%$ \\
\hline Ya & 0 & $0 \%$ \\
\hline
\end{tabular}

\begin{tabular}{|c|c|c|}
\hline Tidak & 12 & $100 \%$ \\
\hline JUMLAH & 12 & $100 \%$ \\
\hline
\end{tabular}

Sumber : Hasil Penelitian 2018

Dilihat dari tabel diatas dapat disimpulkan bahwa di Universitas Padjadjaran tidak ada lembur karena dalam membersihkan pekarangan fakultas, membersihkan jalan tidak perlu ada lembur karena bukan sesuatu yang bersifat urgency yang mengharuskan lembur. Karena yang harus menjaga kebersihan, kenyamanan, kerindangan bukan saja hanya petugas $\mathrm{K} 3 \mathrm{~L}$ tapi seluruh warga masyarakat Universitas Padjadjaran.

\section{KESIMPULAN}

Ketenagakerjaan merupakan segala sesuatu yang berkaitan dengan pekerja/buruh, baik menyangkut hal-hal yang ada sebelum masa kerja (preemployment), selama masa bekerja (duringemployment), maupun sesudah masa kerja. Ketenagakerjaan tidak terlepas dari masalah kesempatan kerja, tenaga kerja dan angkatan kerja. Penduduk suatu negara dapat dibagi dalam dua kelompok, yakni kelompok penduduk usia kerja (tenaga kerja) dan kelompok penduduk bukan usia kerja. Penduduk usia kerja (tenaga kerja) adalah penduduk yang berumur 15 tahun ke atas untuk negara-negara berkembang seperti Indonesia.

Petugas K3L merupakan salah satu pekerjaan yang disediakan oleh Universitas Padjadjaran sebagai salah satu bentuk pemberdayaan masyarakat sekitar Jatinangor dan wilayah lain yang berada di Kabupaten Sumedang untuk membantu dalam mewujudkan pememuhan kebutuhannya. Pekerjaan K3L Universitas Padjadjaran juga digaji per satu bulan. Maka para petugas K3L Unversitas Padjadjaran tersebut akan memperoleh pendapatan.

Pendapatan masyarakat adalah penerimaan dari gaji atau balas jasa dari hasil usaha yang diperoleh individu atau kelompok rumah tangga yang dalam satu bulan digunakan untuk kebutuhan sehari-hari. Sedangkan pendapatan dari usaha sampingan adalah pendapatan tambahan yang merupakan penerimaan lain dari luar aktivitas pokok atau pekerjaan pokok. Pendapatan sampingan yang diperoleh secara langsung dapat digunakan untuk menunjang atau menambah pendapatan pokok. 


\begin{tabular}{|c|c|c|c|c|}
\hline $\begin{array}{c}\text { Prosiding Penelitian \& } \\
\begin{array}{c}\text { Pengabdian Kepada } \\
\text { Masyarakat }\end{array}\end{array}$ & $\begin{array}{c}\text { e ISSN : 2581-1126 } \\
\text { p ISSN : 2442-448X }\end{array}$ & Vol 5, No: 2 & Hal: $137-145$ & Juli 2018 \\
\hline
\end{tabular}

Berdasarkan hasil penelitian yang dilakukan, Universitas Padjadjaran yang menyaring masyarakat Kabupaten Sumedang untuk bekerja sebagai Petugas K3L Universitas Padjadjaran. Universitas Padjadjaran juga $100 \%$ yang membayar gaji kepada para petugas K3L Universitas Padjadjaran. Universitas Padjadjaran melakukan proses seleksi dan penyaringan sebelum para petugas $\mathrm{K} 3 \mathrm{~L}$ ini diterima bekerja sebagai petugas K3L Universitas Padjadjaran. Mereka memberikan Curriculum Vitae (CV) kepada pihak Universitas Padjadjaran selaku lembaga yang membuka peluang pekerjaan bagi masyarakat Kabupaten Sumedang. Pihak Universitas Padjadjaran juga melakukan wawancara kepada calon petugas K3L Universitas Padjadjaran tersebut. Setelah rangkaian pendaftaran petugas K3L selesai, kemudian adanya pengumuman staff petugas K3L Universitas Padjadjaran.

Dari penelitian ini juga menunjukkan bahwa $100 \%$ besarnya gaji yang diterima oleh petugas $\mathrm{K} 3 \mathrm{~L}$ Universitas Padjadjaran adalah sebesar Rp.700.000 sampai Rp. 799.000. Pada saat melakukan wawancara, awalnya gaji yang mereka dapatkan hanya sebesar Rp. 650.000. Kemudian ada kenaikan gaji yang berlangsung dua kali menjadi Rp. 750.000 per bulan. Jadi dapat disimpulkan bahwa rendahnya tingkat pendapatan yang diterima oleh petugas K3L Universitas Padjadjaran. Karena jika dilihat dari Upah Minimum Kabupaten Sumedang, gaji yang diterima oleh petugas K3L Universitas Padjadjaran ini tergolong rendah. Gaji yang mereka terima juga belum mencukupi kebutuhan pokok karena pengeluaran yang mereka keluarkan lebih banyak daripada pendapatan yang mereka terima. Tetapi mereka mengatakan bahwa dengan bekerja sebagai petugas K3L Universitas Padjadjaran cukup membantu untuk kehidupan sehari-sehari daripada sebelumnya bagi mereka yang hanya sebagai ibu rumah tangga yang tidak mendapatkan penghasilan.

Penelitian ini juga menunjukkan bahwa 100\% petugas K3L Universitas Padjadjaran mengatakan tidak ada lembur. Karena dalam membersihkan pekarangan fakultas, membersihkan jalan tidak perlu ada lembur karena bukan sesuatu yang bersifat urgency yang mengharuskan lembur.
Karena yang harus menjaga kebersihan, kenyamanan, kerindangan bukan saja hanya petugas K3L tapi seluruh warga masyarakat Universitas Padjadjaran.

\section{SARAN}

1. Adanya peningkatan gaji oleh Universitas Padjadjaran karena petugas K3L Universitas Padjadjaran merasa gajinya kurang sebanding dengan pekerjaan mereka.

2. Adanya penyuluhan tentang keselamatan dan kesehatan dalam bekerja.

3. Adanya jaminan kesehatan bagi petugas K3L Universitas Padjadjaran karena tidak sedikit petugas $\mathrm{K} 3 \mathrm{~L}$ tersebut hampir tertabrak oleh mahasiswa Universitas Padjadjaran.

4. Lebih ditingkatkan kepekaan oleh pihak Universitas Padjadjaran terhadap petugas K3L Universitas Padjadjaran.

\section{Daftar Pustaka \\ (1) Pengarang buku :}

1. Damanik, Sehat. 2006. Outsourcing dan perjanjian kerja menurut UU No, 13 Tahun 2003 Tentang Ketenagakerjaan, DSS Publishing, Jakarta.

2. Dwiyanto, Agus, \& dkk. (2006). Reformasi Birokrasi Publik di Indonesia. Yogyakarta: Gadjah Mada University.

3. Ekonomi Untuk SMA dan MA kelas XI. (2014). Erlangga.

4. Fakih, D. M. (2013). Analisi Gender. Yogyakarta: PUSTAKA PELAJAR.

5. Sugihastusi, \& Saptiawan, I. H. (2010). Gender dan Inferioritas Perempuan : Praktik Kritik Sastra Feminis. Yogyakarta: PUSTAKA PELAJAR. 


\begin{tabular}{|c|c|c|c|c|}
\hline $\begin{array}{c}\text { Prosiding Penelitian \& } \\
\text { Pengabdian Kepada } \\
\text { Masyarakat }\end{array}$ & $\begin{array}{c}\text { e ISSN : 2581-1126 } \\
\text { p ISSN : 2442-448X }\end{array}$ & Vol 5, No: 2 & Hal: $137-145$ & Juli 2018 \\
\hline
\end{tabular}

6. Suhendi, H., \& Ramdani , W. (2001). Pengantar Studi Sosiologi Keluarga. Bandung: Pustaka Setia.

7. Tunggal, H. S. (2013). Pokok-Pokok Outsourcing. Harvarindo.

\section{(2) Jurnal}

1. Irawan, R. (2014). TENAGA KERJA INDONESIA (TKI) DAN KEHIDUPAN SOSIAL EKONOMI: STUDI TENTANG MASYARAKAT YANG BEKERJA SEBAGAI TENAGA KERJA INDONESIA DI DESA LEMBAH KECAMATAN DOLOPO KABUPATEN MADIUN (Doctoral dissertation, UIN Sunan Ampel Surabaya). Pada

http://digilib. uinsby.ac.id/508/3/Bab\%202.pd $f$ (diakses pada 23 Mei 2018)

2. Liana, Y. (2016). PERAN IBU DALAM MENINGKATKAN PENDAPATAN KELUARGA UNTUK MENANGGULANGI KEMISKINAN. DINAMIKA DOTCOM, $7(2)$. Pada

http://download.portalgaruda.org/article.php ?article $=461720 \& \mathrm{val}=6545 \&$ title $=$ PERAN $\% 20$ IBU\%20DALAM\%20MENINGKATKAN\%20PEN DAPATAN\%20KELUARGA\%20\%20UNTUK\%2 OMENANGGULANGI\%20KEMISKINAN (diakses pada 4 Juni 2018)

3. Najoan, B., Kawengian, D. D., \& Harilama, S. H. (2017). Peranan Komunikasi Tokoh Masyarakat dalam Meminimalisir Kesenjangan Sosial di Kelurahan Mampang Kota Depok Jawa Barat. JURNAL ACTA DIURNA, 6(3). Pada

file://C:/Users/05agt17/Downloads/1737535029-1-SM.pdf (diakses pada 24 Mei 2018)

4. Purwaningseh, W. (2010). ANALISIS PENCARI KERJA MENURUT KELOMPOK UMUR, TINGKAT PENDIDIKAN, DAN GOLONGAN POKOK JABATAN DI KABUPATEN KUDUS
(Doctoral dissertation, Universitas Negeri Semarang).

http://lib.unnes.ac.id/4221/1/8207.pdf

(diakses pada 23 Mei 2018)

5. Setiawan, A. (2014). Pemenuhan Hak Pekerja Outsourcing Yang Bekerja Melebihi Waktu Kerja Normal Di PT Trakindo Utama Balikpapan (Doctoral dissertation, UAJY). Pada http://ejournal.uajy.ac.id/6624/1/JURNAL.pdf (diakses pada $24 \mathrm{Mei}$ )

6. Syah, A. Peranan Ibu Bekerja dalam Peningkatan Pendapatan Keluarga (Studi pada Home Industri di Kelurahan Kulim, Kecamatan Tenayan Raya, Pekanbaru). Pada https://repository.unri.ac.id/xmlui/bitstream/ handle/123456789/673/jurnal.pdf?sequence $=1$ (diakses pada 4 Juni 2018)

7. Triyono, N. F. N. (2016). OUTSOURCING DALAM PERSPEKTIF PEKERJA DAN PENGUSAHA. Jurnal Kependudukan Indonesia, 6(1), 45-62. Pada file://C:/Users/05agt17/Downloads/88-3981-PB.pdf (diakses pada 24 Mei 2018)

8. Zenitho Nuari, Pasca. Peranan Indutri Rumah Tangga dalam Peningkatan Pendapatan Keluarga (Studi Pekerja Ibu Rumah Tangga pada Home Industri Pangan di Kelurahan Sungai Beringin, Kecamatan Tembilahan, Kabupaten Indragiri Hilir). Pekanbaru: Skripsi Sosiologi FISIP UR, 2008

\section{(3) Rujukan Elektronik}

1. BPS Kabupaten Sumedang, Kabupaten Sumedang Dalam Angka 2017

2. file:///C:/Users/05agt17/Downloads/UMKProvinsi-Jawa-Barat-Tahun-2018.pdf (Keputusan Gubernur Jawa Barat Nomor : 561/Kep.1065-Yanbangsos/2017) 